\title{
Effect of Service Quality and Perceived Value Satisfaction and Loyalty Religious Tourists Visit Island Madura, Indonesia
}

\author{
Pribanus Wantara ${ }^{1 *}$ \\ ${ }^{1}$ Trunojoyo University, Madura, Indonesia
}

\begin{abstract}
This paper wants to examine the relationship of service quality, perceived value, satisfaction and loyalty with religious tourists who visit the island of Madura in 2015. The structural equation modeling results support the hypothesis that service quality affects directly the satisfaction and loyalty, and satisfaction directly affects loyalty, but the results do not support the hypothesis that the perceived value directly affects the satisfaction and perceived value directly affects loyalty. Quality of service only has direct and indirect influence on loyalty through satisfaction. So the stage of tourism development in Madura, quality of service is very important in building loyalty and satisfaction tourists.
\end{abstract}

Keywords: Loyalty, Madura Island, Perceived Value, Satisfaction, Service Quality

\section{INTRODUCTION}

In the period of the last decade in some countries there is a new paradigm, that the religious journey packaged in religious tourism. Religious tourism is done by visiting the holy places and ancient buildings such as mosques, churches, temples, tombs of saints or religious figures, and other sacred places. People come to the holy site not only for worship, pilgrimage, or meditation, but they can learn about the history and archeology also traveling. So that the activity of worship, pilgrimage, learning about the history and archeology in the holy sites, as well as travel can be classified as religious tourism (Center for Research and Promotion of Tourism in 2006, Najib, 2008). With this condition, it can be one of the tourism industry can be expected to be the main source of income of the region or country.

After the longest bridge was completed and inaugurated by the President in 2009, interest in religious tourism visit to the island of Madura higher. This is supported by a sense of obedience Madurese to seek religious leaders or scholars making the island area of approximately 5,168 km2 known as area of santri (muslim students) and even some people mentioned that Madura as a portico Medina, as evidenced by the number of schools as well as religious leaders or scholars who emerged from the island with a population of nearly 6 million. Although religious leaders are now gone, but obedience to the scholars Madurese very large. They are often regarded as a tomb of Kiai (scholars) that is believed to be the most appropriate place in addition to praying for the souls of scholars and also to pray to God with a specific purpose. The number of tourists who visit the tombs of Kiai (scholars) make such a religious tourist destination in Madura. Here

* Corresponding author. Email address: pribanus@gmail.com 
are four potential of religious tourism on the island of Madura, which became the main destination for tourists visiting the island of Madura: First, Tomb Syeikhona Cholil - Bangkalan, Tomb Syeikhona Cholil, in the area Martajasah-Bangkalan is one of the important places in Madura Island visited by many pilgrims who come from various regions both inside and outside the region, in addition to the Tomb of Ebuh Tears which is also located in the town of Bangkalan. The tomb complex of this great scholar is always visited by pilgrims and tourists, day or night. In this complex there are also magnificent mosques award winner number two of the most beautiful mosques in East Java. Secondly, the Tomb of Ratu Ebu-Sampang, religious tourism object located in the village Polagan, Sampang district and reach $2 \mathrm{~km}$ from the city center to the south. Tomb of Ratu Ebu is a tourist attraction in the form of the tomb of the great scholars who led the kingdom in ancient times which is the tomb of the King of Sampang "R. Praseno" who died in 1624. Third, Batu Ampar-Pamekasan, grave Batu Ampar, is the tomb of influential cleric in Pamekasan and the equivalent of Wali Songo. The cemetery is located in the village of Batu Ampar, District Guluk-guluk, which is about $15 \mathrm{Km}$ from the city center. As Tourism location that visited by people who want to pray and make pilgrimages in the tomb Islamic spreader leader in Pamekasan. Fourth, Tomb Asta Tinggi - in Sumenep, Asta Tinggi is the Kings tomb of Sumenep which was built around the 1750 , arrive at your location will be made stunned by a magnificent gate and high artistic value. This place is so sacred, even the children of kings in Sumenep still have pilgrimage to this place before entry / stay / visit Kraton Sumenep. Thus, visitors are required to take their shoes off at the front gate of each tomb (also maintain modesty clothing and behavior). Every day the tombs never empty of visitors, especially on days of Islam, sometimes must be willing jostling to get into the cemetery. However, everything will be paid for treating the architecture which resembles a Portuguese building. There is a growing belief in the community, anyone who is able to finishing Al-Quran in this place will surely make fluent reading the Qur'an. The next, to attract tourists, the necessary facilities and infrastructure to visit religious tourist sites, such as access roads, places of worship adequate, parking lots, rest areas, locations merchandise sales, service personnel were friendly and so on. For long-term development with intense competition, many companies do not only focus on attracting new customers, but also to secure and increase customer loyalty. The new work on the determinants of loyalty has emphasized the importance of perceived quality, perceived value and customer satisfaction (Cronin et al, 2000, Kashyap and Bojanic, 2000, Petrick 2004 Duman and Mattila 2005 Meng et al, 2011). However, the extent to which the perception of service quality, perceived value, satisfaction and loyalty are connected to one another is uncertain in the literature. This research is expected to contribute to the literature investigating the relationship between perceived quality, perceived value, customer satisfaction and loyalty religious tourists who visit religious places on the island of Madura. 


\section{LITERATURE STUDY/HYPOTHESIS DEVELOPMENT Service quality}

Parasuraman et al. $(1985,1988)$ developed the SERVQUAL instrument, which consists of 22 attributes are incorporated in the five dimensions (ie, reliability, assurance, tangibles, empathy and responsiveness). They define the quality of service as a difference or gap between customer expectations and perceived performance and proposes to use the value gap to measure the quality of service. Although SERVQUAL increasingly widespread use in various industries and countries, some experts such as Brady et al. (2002), Cronin and Taylor (1992, 1994) states that the quality of service is more accurate when judged by the quality perception than the value of "gap". Another criticism against the SERVQUAL instrument consists of 22 attributes considered inappropriate, or say that they can not be adopted to measure the quality of service in all service industries (Cronin and Taylor, 1992). Meanwhile, according to Ladhari (2009), there are 30 specific measures on quality of service industry that has developed between 1990 and 2007 in different industries and countries.

\section{Perceived Value}

Zeithaml (1988) defines perceived value as "an overall assessment of the usefulness of consumer products based on the perception of what was acceptable and what is excluded". The perceived value can be analyzed with the size of the item that is in terms of "value for money" (Sweeney et al 1996). However, many researchers recommend that perceived value is measured using a multidimensional scale (Sweeney and Soutar 2001; Chen, 2008, Lee et al 2007). Sweeney and Soutar (2001) even developed a model of perceived value, named PERVAL. Meng et al (2011) considers the non-monetary aspects can also be used to evaluate the perceived value in the shipping industry. Monroe (in Kristanto, 2005) reveals that in order to assess whether the performance of the products of a brand can create value, based on the four components of perceived value that is costs, exchange rates, aesthetics, and function relatively. The concept of the value proposed by Monroe described as follows: (1) cost (cost), is the total money spent or paid by consumers to acquire and consume a service. (2) the value of the exchange (exchange value), is the value received by the consumer in touch with the ease obtained consumers to consume a service; (3) aesthetics is the value which consumers feel happy and comfortable with the services acquired. (4) The relative function is how a service is used, as well as its ability to reduce costs or generate certain advantages for consumers. With the achievement of an optimum level of customer satisfaction that encourages loyalty in the minds of customers who are satisfied earlier.

\section{Customer satisfaction}

According to Oliver $(1997,2010)$, customer satisfaction is defined as an assessment that the products or services provided have fun meet consumption levels associated. Also there are two levels of the individual consumer satisfaction: satisfaction transaction-specific and cumulative satisfaction. Transaction-specific satisfaction or the satisfaction of meeting compliance identified as a response to a transaction or meetings, while the cumulative satisfaction is based on the 
assessment of events much the same experience and not just a one time experience. For both cases (satisfaction and contentment meetings cumulative), the satisfaction of both defined as an overall assessment of satisfaction or decomposed into satisfaction with the performance or quality attribute (Cronin and Taylor 1992). "Overall" "cumulative" satisfaction is commonly used by researchers such as Mittal et al. 1999 and Spreng et al. 1996.

\section{Loyalty}

According to Oliver $(1997 ; 2010)$, loyalty is defined as "a commitment that are held to buy back the products or services that are favored consistently in the future, leading to repeat sales on the same brand, despite situational influences and marketing efforts that have the potential to cause the switch behavior ". There are two approaches to customer loyalty: the behavior and attitude. Loyalty behavior refers to actual customer behavior to repeat purchase products or services and recommend the loyalty attitude while referring customer's intention to repurchase and willingness to recommend. Loyalty attitude is more commonly used in many research studies (Loureiro and Kastenholz 2011) and is relatively easy to measure.

The relationship between service quality, perceived value, satisfaction, and loyalty

There are several previous studies that explore the relationship quality satisfaction and loyalty. It is generally believed to industrial and service marketing that (1) a good quality service will generate customer satisfaction, (2) good quality services will attract customers that can lead to customer loyalty, and (3) high level of satisfaction will tend to create loyalty customer. However, it has also been submitted that satisfaction may not be sufficient to generate loyalty, despite the loyal customers almost generally satisfied (Cronin and Taylor 1992; Cronin et al., 2000, Petrick, 2004). Furthermore, many researchers claim that the perceived value is the determinant of customer satisfaction (Patterson and Spreng, 1997, Petrick and Backman, 2002) and loyalty (Petrick, 2004; Eggert and Ulaga, 2002).

Based on the literature review above, this study establishes the hypothesis as follows:

H1: Service quality is a significant effect, positive, and direct to customer satisfaction.

$\mathrm{H} 2$ : Service quality is a significant effect, positive and direct to loyalty.

H3: The perceived value significant influence, positively and directly on customer satisfaction.

H4: The value perceived value significant influence, positively and directly to loyalty.

H5: Customer satisfaction have significant influence, positively and directly to loyalty.

\section{RESEARCH METHODOLOGY}

Data collection and measurement

The measurement instrument for the empirical study was developed in three phases. First, some of the relevant items for the questionnaire were taken from the literature. For the measurement of service quality, adopted items from the SERV- 
PERF scale (Cronin and Taylor, 1992) were used. Items for measurement of perceived value were adopted from Cronin et al. (2000) and Gallarza and Saura (2006). For measurement of customer satisfaction, items from Oliver's (1993) scale were used. Additionally, to representatively capture the customer loyalty, we used items adopted from Nguyen and Leblanc (2001). Second, in-depth interviews with 40 tourists of different genders, ages, education levels, and from different cities were conducted in order to generate an additional of information. In the final study, the items for service quality, perceived value, and customer loyalty were measured on a five-point Likert scale (one ="strongly dis agree" to five="strongly agree"). Seventeen items were used for measurement of service quality, the scale for perceived value consists of four items, while the scale for loyalty of four items. Satisfaction was also measured on a five-point scale, ranging from "very dissatisfied" to "very satisfied." Data for the main research was collected from 200 tourists in December 2015, by means of a personal interview. For each of the three destinations, the quota sample framework followed there presentative tourist structure by the cities of origin. Due to control over the respondent selection, we believe that relevant units were in cluded.

\section{Research Data}

The data used in this study were collected through a questionnaire survey on pilgrims who came to Madura island taken by accidental as a sample to fill out a questionnaire. Of the total questionnaires of 200 pieces, the final number of valid questionnaires was 154 after eliminating 46 of 200 questionnaires were returned due to either incomplete information or questions not answered. After the steps suggested in Cooper and Emory, 154 samples were then tested using Cronbach test to ensure the reliability of the sample to represent the population in this study (Cooper and Emory, 1995; Cronbach, 1951). Characteristics of respondents who support this study are described as follows: based on the characteristics of the sex of the respondents consisted of: 92 male respondents and 62 female respondents; based on the characteristics of the age of the respondents: 94 respondents aged under 40 years; 60 respondents aged above 41 years.

\section{RESULTS}

An internal consistency test was conducted in regard to the whole data of participants for each variable in the study's questionnaire.

\section{Reliability Test}

An internal consistency test was conducted in regard to the whole data of participants for each variable in the study's questionnaire.

Table 1 Internal Consistency of Study's Questionnaire

\begin{tabular}{lcc}
\hline \multicolumn{1}{c}{ Variabel } & No. of Items & Cronbach Alpha \\
\hline Service Quality (SQ) & 21 & .873 \\
Perceived Value (PV) & 4 & .763 \\
Satisfaction (S) & 3 & .706 \\
Loyalty (L) & 3 & .751 \\
\hline
\end{tabular}


The results indicated that a Cronbach's Alpha coefficient was $\alpha=.873$ for service quality, $\alpha=.763$ for perceived value, $\alpha=.706$ for tourist satisfaction, and $\alpha=.751$ for tourist loyalty as shown in Table 1 . The reliability of multi-item scales was assessed by Cronbach's alpha coefficient. For all four scales used to operationalize the constructs investigated, Cronbach's alpha coefficient value was higher than 0.70. According to Churchill (in Zineldin and Jonsson, 2000) a value of Cronbach's alpha coefficient of 0.70 or higher is considered acceptable and indicates that the measurement scale tested is reliable. Therefore, the measurement scales used in this study are reliable.

\section{Measurement of Structural Equation Modeling (SEM) Overall}

After measurement models for each factor or construct using Confirmatory Factor Analysis (CFA), which produces the information that each of the factors / indicators that support the research model each have been received with a value of loading factor that is significant or reliable, then analyzed the relationship causality in a structural equation model or SEM (Structural equation Modeling) overall. The model is said to be good when development hypothetical model theoretically supported by empirical data. Detailed SEM analysis results are shown in Figure 1.

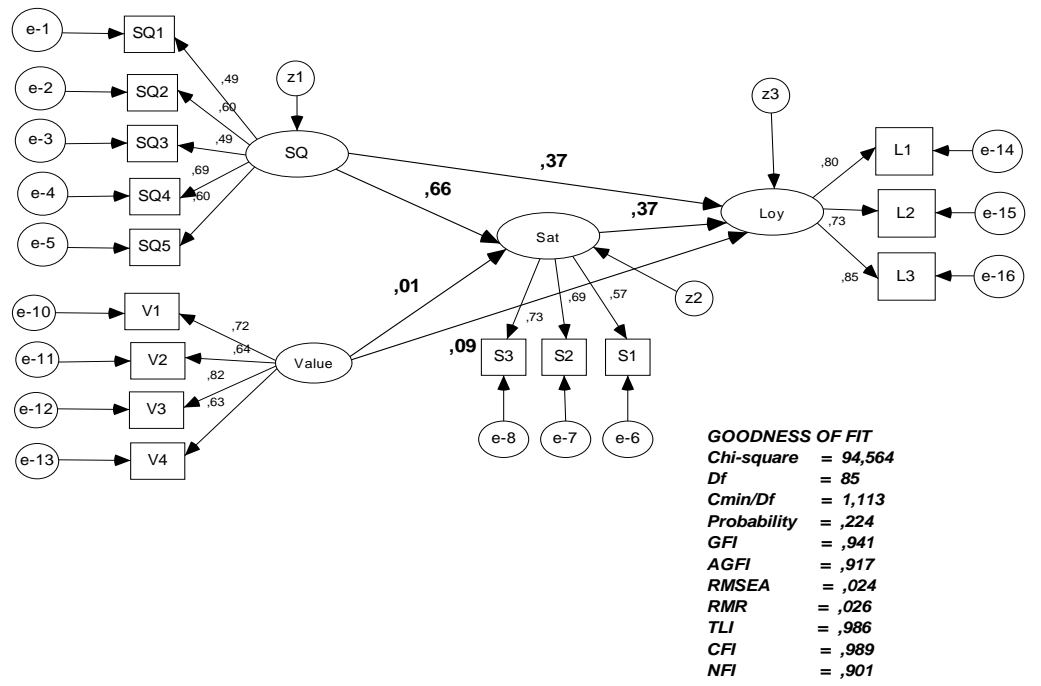

Figure 1 Research Model Path Coefficients

The result of the model presented in Figure 1 further evaluated using the goodness of fit indices and the results are shown in Table 2.

Table 2 Fit Indices of The Research Model

\begin{tabular}{lc}
\hline \multicolumn{1}{c}{ Statistic } & Value \\
\hline$\chi 2(\mathrm{df})$ & 94.564 \\
Probability value for $\chi 2$ statistic $(\mathrm{p})$ & .224 \\
$\chi 2 / \mathrm{df}$ & 1.113 \\
Root Mean Square Error of Approximation (RMSEA) & .118 \\
Goodness of fit index (GFI) & .941 \\
Adjusted Goodness of fit index (AGFI) & .917 \\
\hline
\end{tabular}




\begin{tabular}{lc}
\hline \multicolumn{1}{c}{ Statistic } & Value \\
\hline Normed Fit Index (NFI) & .901 \\
Comparative Fit Index (CFI) & .989 \\
Tucker-Lewis Index (TLI) & .986 \\
\hline
\end{tabular}

Evaluation of the proposed model indicates that an evaluation of the overall construct criteria of good result because there are no critical violations, considering the measurement has met all the terms it was concluded that the model can be received or said to have been in accordance with the data in order to test the suitability of the model further.

\section{CONCLUSION}

The results showed that the quality of service supported by indicators of reliability, assurance, tangibles, empathy and responsiveness proven to provide a significant positive effect on the level of $5 \%$ of customer satisfaction and loyalty tourists come to the island of Madura. This illustrates that if the dimensions of service quality on a religious tourism on the island of Madura can be maintained even can be improved then this condition will provide support to increase customer satisfaction and loyalty for tourists religion to visit the locations of the religious on the island of Madura, thus increasing income and income of the people on the island of Madura. The perceived value that is supported by the four components of perceived value that is costs, exchange rates, aesthetics, and function relatively. proven to provide a significant positive effect on the level of $5 \%$ of the marketing capabilities. This means that, if the higher ability of an area to show the value of a good tourist location, it can increase customer satisfaction and loyalty religious tourists come to the island of Madura.

Furthermore, through SEM analysis showed that the quality of the services affect satisfaction and loyalty. However, it was found that the perceived value does not have a direct and significant effect on satisfaction and loyalty. So to increase loyalty for the tourists visiting the island of Madura is to improve the quality of service is more important than increasing the perceived value and satisfaction. There are several limitations to this study. Generalization of this study is limited because of three reasons. First, the data collected from 154 tourists in two group trips in one month. Larger sample sizes it is possible to understand the determinants of loyalty to the religious tourists visiting the island of Madura. Second, this study used only a single item to measure satisfaction and perceived value to reduce the burden on respondents and time for the interview. For further research, some items are preferred so that the validity and reliability they can be assessed through CFA. Also they can improve the interpretation and prediction of perceived value, satisfaction and loyalty. Third, the analysis is based on a collection of survey data collected in December 2015 further research is needed to test whether the relationship between service quality, perceived value, customer satisfaction and customer loyalty with the conditions of changing times. 


\section{References}

Brady, M.K., Cronin, J.J., \& Brand, R. (2002). Performance Only Measurement of Service Quality: A Replication and Extension. Journal of Business Research, 55, 17-31.

Chen C.F. (2008). Investigating Structural Relationships Between Service Quality, Perceived Value, Satisfaction, and Behavioral Intentions For Air Passengers: Evidence from Taiwan. Transportation Research, Part A, 42, 709-717.

Cooper, D.R., \& Emory, C.W. (1995). Business Research Methods (5th ed.). Chicago: Irwin.

Cronbach, L.J. (1951). Coefficient Alpha and The Internal Structure of Tests. Psychometrika, 22(3), 297-334.

Cronin, J. J., \& Taylor, S. A. (1992). Measuring Service Quality: A Reexamination and Extension. Journal of Marketing, 56 (July), 55-68.

Cronin, J.J., \& Taylor, S.A. (1994). SERVPERF versus SERVQUAL: Reconciling Performance-based and Perceptions-minus-expectations Measurements of Service Quality. Journal of Marketing, 58, 125-131.

Cronin, J.J., Brady, M.K., \& Hult, G.T.M. (2000). Assessing The Effects of Quality, Value, and Customer Satisfaction on Consumer Behavioral Intentions in Service Environments. Journal of Retailing, 76(2), 193-218.

Duman, T., Mattila, A.S. (2005). The Role of Affective Factors on Perceived Cruise Vacation Value. Tourism Management, 26(3), 311-323.

Eggert, A., \& Ulaga, W. (2002). Customer Perceived Value: A Substitute For Ssatisfaction in Business Markets. Journal of Business and Industrial Marketing, 17(2/3), 107-118.

Gallarza, M.G., \& Saura, I.G. (2006). Value Dimensions, Perceived Value, Satisfaction and Loyalty: An Investigation of University Students` Travel. Tourism Management, 27(2), 437-452.

Kashyap, R., \& David, B. (2000). A Means-End Approach to Investigating the Influence of Perceived Value on Customer's Purchase Intentions. Developments in Marketing Science, XXIII. Harlan Spotts and H. Lee Meadow, (Eds.), Coral Gables, FL: The Academy of Marketing Science.

Kristanto, A. (2005). Analisis Pengaruh Asosiasi Merek, Nilai Produk, dan Kualitas Pelayanan Terhadap Kepuasan, Serta Hubungannya Dengan Retensi Konsumen: Studi Mengenai Motor Merek Honda di Jakarta. [Tesis]. Jakarta: Program Studi Magister Manajemen UI.

Ladhari, R. (2009). A Review of Twenty Years of SERVQUAL Research. International Journal of Quality and Service Sciences, 1(2), 172 - 198.

Ladhari, R. (2008). Alternative Measures of Service Quality: A Review. Managing Service Quality, 18, 65-86.

Lee, C.K., Yoon., Y.S., \& Lee, S. K. (2007). Investigating The Relationships Among Perceived Value, Satisfaction, and Recommendations: The Case of the Korean DMZ. Tourism Management, 28, 204-214.

Loureiro, S.M.C., \& Kastenholz, E. (2011). Corporate Reputation, Satisfaction, Delight, and Loyalty Towards Rural Lodging Units in Portugal. International Journal of Hospitality Management, 30, 575-583.

Meng, S. M., Liang, G.S., \& Yang, S.H. (2011). The Relationships of Cruise Image, Perceived Value, Satisfaction, and Post-purchase Behavioral 
Intention on Taiwanese Tourists. African Journal of Business Management, 5(1), 19-29.

Mittal, V., Kumar, P., \& Tsiros, M. (1999). Attribute-level Performance, Satisfaction and Behavioral Intentions Over Time: A Consumption-system Approach. Journal of Marketing, 63(2), 88-101.

Najib, U. (2008). Wisata Pilgrimage: Upaya Preservasi Sumberdaya Arkeologi yang Dimanfaatkan Sebagai Objek Wisata. Pusaka Budaya dan Nilai-nilai Religiusitas. Jurusan Arkeologi Fakultas Sastra Universitas Udayana. Denpasar. Hal: 121-137.

Nguyen, N., \& Leblanc, G. (2001). Corporate Image and Corporate Reputation in Customers' Retention Decisions in Services. Journal of Retailing and Consumer Services, 8, 227-36.

Oliver, R.L. (1993). A Conceptual Model of Service Quality and Service Satisfaction: Compatible Goals, Different Concepts. in Swartz, T.A., Bowen, D.E. and Brown, S.W. (Eds), Advances in Services Marketing and Management, 2, 65-85.

Oliver, R.L. (1997, 2010). Satisfaction: A Behavioral Perspective on The Consumer. New York: McGraw Hill.

Petrick, J.F. (2004). The Roles of Quality, Value and Satisfaction in Predicting Cruise Passengers' Behavioral Intentions. Journal of Travel Research, 42, 397-407.

Parasuraman, A., Zeithaml, V.A., \& Berry, L.L. (1985). A Conceptual Model of Service Quality and Its Implications For Future Research. Journal of Marketing, 49, 41-50.

Parasuraman, A., Zeithaml, V.A., \& Berry L.L. (1988). SERVQUAL: A Multiple Item Scale for Measuring Consumer Perceptions of Service Quality. Journal of Retailing, 64, 12-40.

Patterson, P.G., \& Spreng, R.A. (1997). Modelling The Relationship Between Perceived Value, Satisfaction and Repurchase Intentions in a Business-tobusiness, Services Context: An Empirical Examination. International Journal of Service Industry Management, 8(5), 414-434.

Petrick, J.F., \& Backman, S.J. (2002). An Examination of The Construct of Perceived Value For The Prediction of Golf Travelers; Intentions to Revisit. Journal of Travel Research, 41(August), 38-45.

Pusat Penelitian dan Pengembangan Kepariwisataan. (2006). Penelitian Pengembangan Wisata Religi. Jakarta: Departemen Kebudayaan dan Pariwisata.

Spreng, R.A., MacKenzie, S.B., \& Olshavsky, R.W. (1996). A Re-examination of The Determinants of Consumer Satisfaction. Journal of Marketing, 60(3), p15-32.

Sweeney, J.C., Soutar, G.N., \& Johnson, L.W. (1996). Retail Service Quality and Perceived Value: A Comparison of Two Models. Journal of Retailing and Consumer Services, 4(1), 39-48.

Sweeney, J.C., \& Soutar, G.N. (2001). Consumer Perceived Value: The Development of A Multiple Item Scale. Journal of Retailing, 77(2), 203220. 
Effect of Service Quality and Perceived Value Satisfaction and Loyalty Religious Tourists Visit Island Madura, Indonesia

Zineldin, M., \& Jonsson, P. (2000). An Examination of the Main Factors Affecting Trust/Commitment in Supplier-Dealer Relationships: An Empirical Study of Swedish Wood Industry. The TQM Magazine, 12(4), 245-265. 